\title{
Who writes African economic history?
}

\author{
JOHAN FOURIE
}

\section{Stellenbosch Economic Working Papers: WP09/2019}

www.ekon.sun.ac.za/wpapers/2019/wp092019

May 2019

KEYWORDS: economic history, Africa, bibliometric, citations JEL: N01

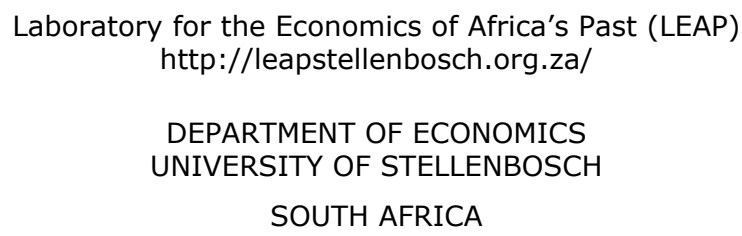

A WORKING PAPER OF THE DEPARTMENT OF ECONOMICS AND THE BUREAU FOR ECONOMIC RESEARCH AT THE UNIVERSITY OF STELLENBOSCH 


\title{
Who writes African economic history?*
}

\author{
Johan Fourie ${ }^{\dagger}$
}

\begin{abstract}
Much has been said about the rise, or 'renaissance', of African economic history. What has received far less attention is who is producing this research. Using a complete dataset of articles in the top four economic history journals, I document the rise in African economic history in the last two decades. I show that although there has indeed been an increase in papers on Africa, it has included little work by Africans. I then attempt to explain why this is so, and motivate why this should matter. The good news is that, mostly owing to efforts by the academic community, more is being done to encourage African inclusion. I conclude with a few suggestions on how to make more African scholars part of the renaissance of African economic history.
\end{abstract}

Keywords. economic history, Africa, bibliometric, citations

${ }^{*}$ This paper is prepared for a special issue of Economic History of Developing Regions. I am grateful also to Felix Meier zu Selhausen for sharing statistics about the African Economic History Network, and to Kudzai Chidamwoyo, Calumet Links, Lisa Martin and Heinrich Nel for their data collection efforts. A preliminary version of this paper was presented at the African Economic History workshop at Stellenbosch University on 15 April 2019. I received helpful comments from Gareth Austin, Fran Marco Gracia, Alfonso Herranz-Loncán, Nobungcwele Mbem, Felix Meier zu Selhausen, Elie Murard, Amy Rommelspacher and Krige Siebrits. I particularly appreciate the fruitful discussions with the many LEAP visitors and, in particular, with Erik Green, who has done much to expand African economic history on the continent.

${ }^{\dagger}$ LEAP, Department of Economics, Stellenbosch University. Email: johanf@sun.ac.za. 


\section{Introduction}

There is no doubt that African economic history, much like the continent's economic prospects, is on the rise. The African Economic History Network meets annually since 2005. Attendance of its annual conferences has increased by a factor of 10 since 2009, with more than 70 papers presented at the 2018 AEHN meetings in Bologna. Figure 1 plots this remarkable growth. The Network now hosts a website with a blog that summarises recent key contributions to the field of African economic history (and which receives more than 30,000 hits annually), an active working paper series, and publishes a bi-monthly newsletter (Meier zu Selhausen 2018). It has published an open-access textbook of fourteen chapters - The History of African Development (2018) - with most downloads originating in African countries ${ }^{1}$. All this scholarly activity has also translated into more published output. In 2018, the top four economic history journals published seven papers on African topics. Ten years earlier, in 2008, it was one. In 2014, Austin and Broadberry (2014) labeled this renewed interest in African economic history a 'renaissance'.

Yet one aspect of this 'renaissance' is less laudable: Africans are largely absent from it. This short paper uses a new dataset of publications in the top four economic history journals over the past two decades to show, first, the rise in African economic history and, second, the lack of participation by African scholars. I find additional evidence that confirm the trend is not unique to the four journals I consider. An econometric exercise suggests that it is not a demand-side constraint either; journal editors are not biased against African topics.

This is not a bibliometric study of the factors that determine citation success. Several of these have appeared on economic history (Di Vaio et al. 2012; Seltzer and Hamermesh 2018) and economics more generally (Hamermesh 2018). This paper is concerned more narrowly with the factors that have prevented and continue to prevent - more African scholars from publishing in top economic history journals. I motivate why this is an issue of importance, review existing debates, note some progress, and conclude with three recommendations to encourage African scholars to join in debates about the economic histories of their own continent.

\section{Journals}

To investigate the rise of African economic history, I constructed a new dataset of 2293 papers published in the top four economic history journals - The Economic History Review (EHR), Journal of Economic History (JEH), Explorations in Economic History (Explorations), and European Review of Economic History (EREH) - from 1998 to 2018. The full universe of papers are included. These are the top ranked journals in economic history (Di Vaio and Weisdorf 2010). An obvious question may be why it would be important for economic historians to publish in these journals, rather than leading economics, history or regional journals. The flippant response would be that the best economic historians publish in the best journals; if a scholar wants to be counted as a leader in their field, they have to publish in the field's leading journals. A more thoughtful response might be that these four journals, because of the large number of submissions they receive which forces them to apply rigorous standards of evaluation, publish the best papers. They, therefore, also attract the largest readership. Their impact factors suggest that papers published there are cited more frequently than elsewhere, having a larger, well, impact. Scholars' prestige in the field, and therefore their access to funding, is indeed linked to how often they publish in the best journals. This is not to say that the best scholars do not also publish excellent research elsewhere. But it is plausible to suggest that a general consensus of the leading economic historians globally would be closely correlated with how often these scholars publish in the top four journals.

The dataset includes the title, volume, issue, order (in which the paper appear), and author details (name, university affiliation and country of affiliation for each of the authors). I also classify the geographic scope of each paper, and call this 'Region'. Table 1 provides a breakdown of the descriptive statistics by region and journal.

An important concern could be that the choice of journals may bias the inferences. There are indeed several excellent economic history journals outside these four, including Cliometrica, Revista de Historia

\footnotetext{
${ }^{1}$ The textbook is used as prescribed material in at least four African countries
} 


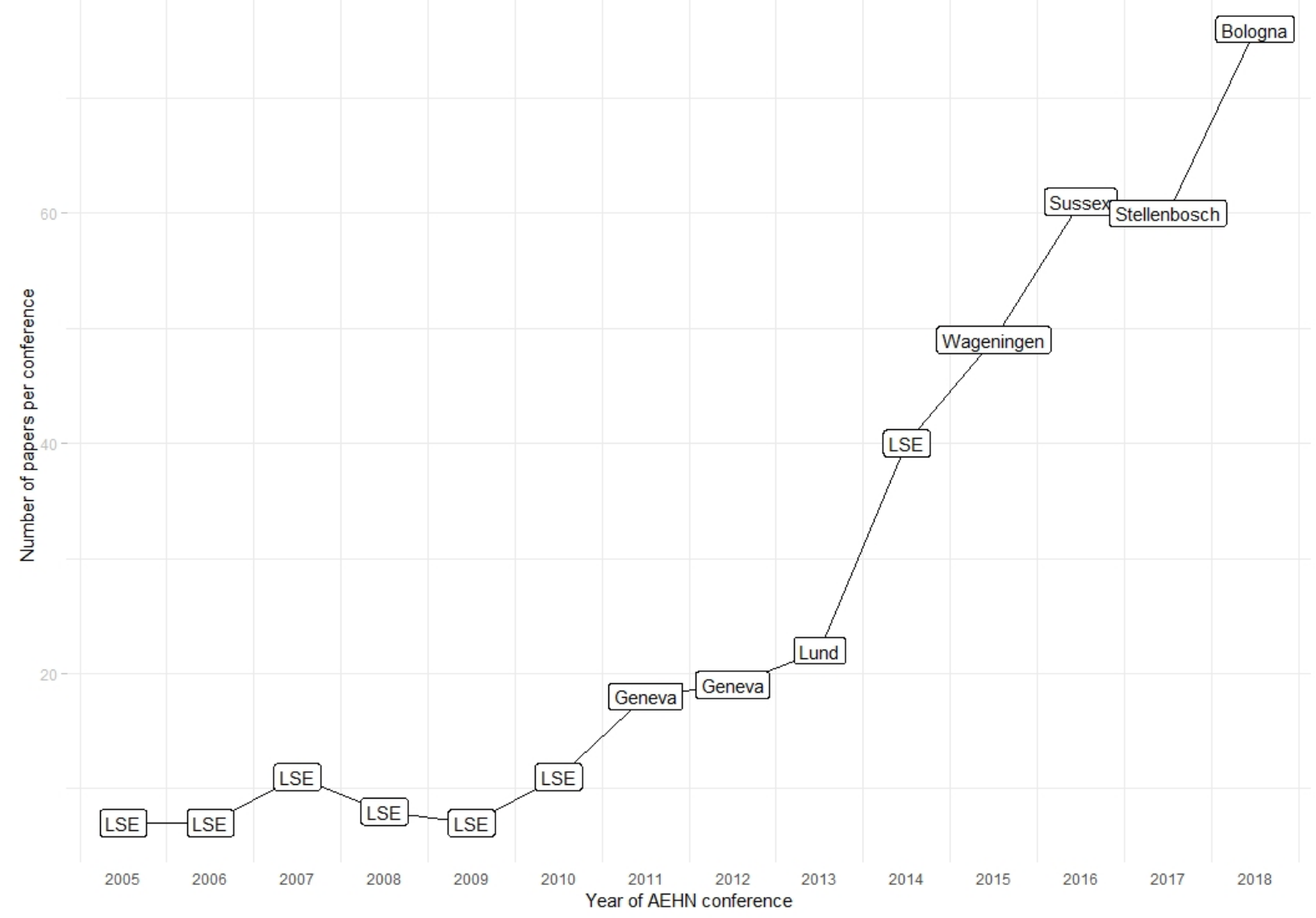

Figure 1: The number of conference papers at the African Economic History Network meetings, 2005-2018

Económica and Economic History of Developing Regions (EHDR). Although somewhat dated by now, I follow the ranking of Di Vaio and Weisdorf (2010) who show, using citation analysis, the leading performance of these four journals. I acknowledge the many excellent papers in more regional journals; The Australian Economic History Review and The Indian Economic and Social History Review are likely to attract more papers on Asia and Oceania, the Revista on Latin America, and African Economic History and EHDR on Africa. But while there are many other avenues for publishing economic histories of developing countries, this is also true of the economic histories of Europe. Consider, for example, the Scandinavian Economic History Review, Low Countries Journal of Economic and Social History and the Irish Economic and Social History. I make the assumption that an analysis of the top four journals would broadly highlight publication patterns pervasive throughout the discipline. ${ }^{2}$

Figure 2 shows the number of papers, by year, published in the top four journals. The colours indicate the geographical scope, or region, of each paper. This classification is based on my own interpretation of the paper's geographical scope. Most papers have a clear geographical focus - often indicated in the title which makes classification easy. Others require more interpretation. My preference was to sort papers into a single country or continent, but some papers were cross-country studies that I grouped into 'Global'.

The rise in African economic history can be seen from Figure 2. Only seven papers on Africa were published from 1998 to 2008. In the decade after, this number increased seven-fold, to 53. What is also clear from Figure 2 is that this increase has not come at a cost in the number of papers that cover other world

\footnotetext{
${ }^{2}$ This assumption is probably more valid during the last few decades. As Austin (2018) notes in his inaugural lecture at Cambridge University in October 2018, this assumption was certainly not true in earlier years, including during the original 1960s to mid-1980s era of fairly plentiful research on African economic history.
} 


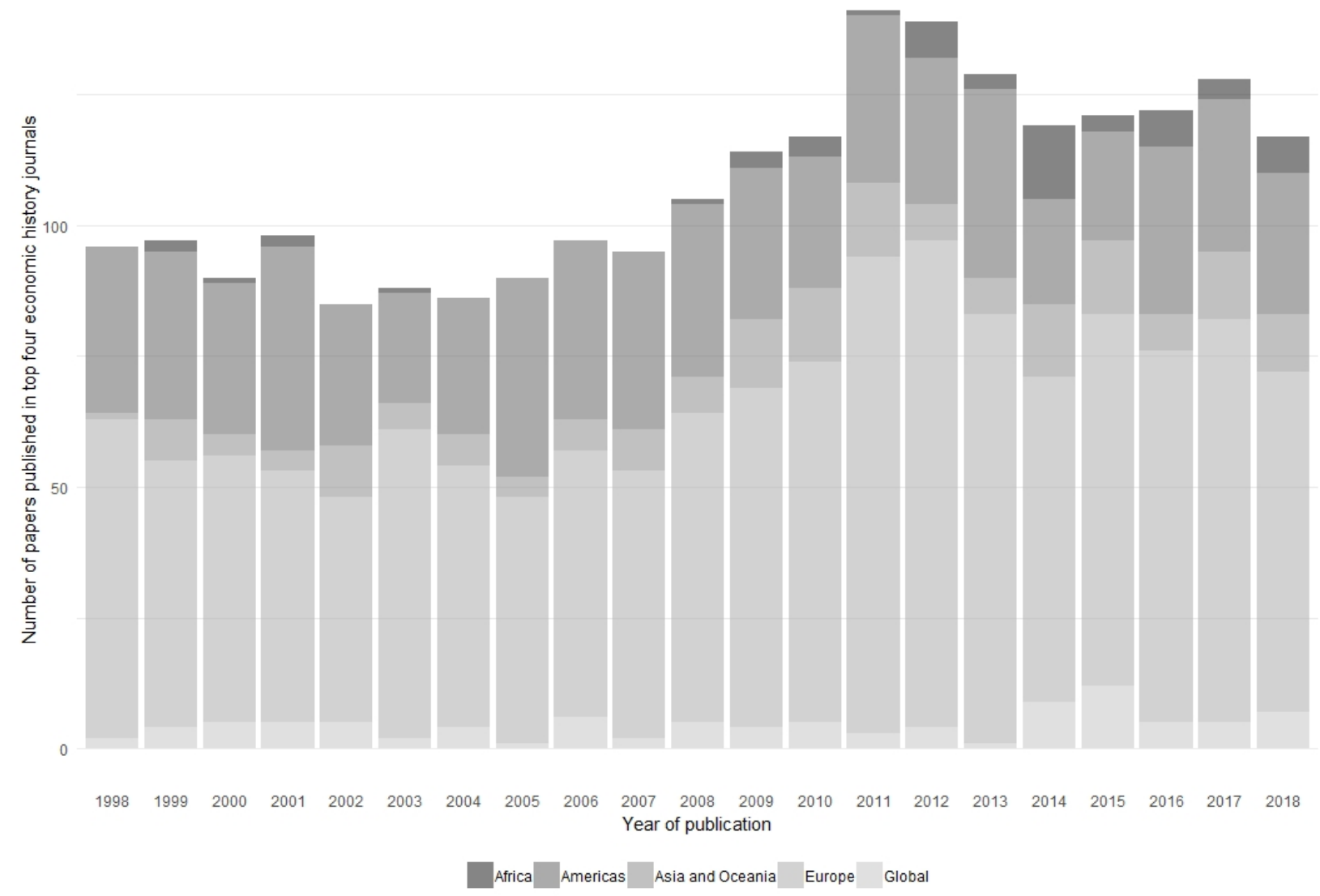

Figure 2: The number of papers published in the top four economic history journals, by year and region

regions. The total number of papers published in the top four journals has increased by about $20 \%$ in the last decade.

I report the destriptive statistics for the entire dataset, by region and journal, in Table 1. The averages of order number, issue number, page length, number of authors and Google citations are reported, as well as the total number of pages and the maximum Google citations. Google citations were collected manually in March 2019.

Table 1 confirms the low number of papers on Africa that could be seen in Figure 2. Of the 713 papers published by EHR, only 31 papers, or $4.4 \%$ were on Africa. These numbers are even lower for the other three journals, as Table 2 shows. There are no obvious trends that differentiate Africa papers. Although the average order number per issue for Africa papers published in the $E H R$ is lower, this is not true for the $J E H$ or $E R E H$. While Africa papers also tend to appear in later issues of the $E H R$, the same is not true for other journals. Neither are Africa papers particularly short or long, nor have they more authors. Comparing the average number of citations for papers on Africa with those of other regions suggests that Africa papers are at the lower-end of the distribution. Figure 3 shows this visually. There seems to be some variation between the journals; the median citations core for Africa papers in the $E H R$ is on par or above almost all the other regions. The same is true for $E R E H$. But Africa papers generally perform poorly in $J E H$ and, in particular, in Explorations. This may simply be an age-effect; very few papers on Africa appeared during earlier years, which means that Africa papers have consequently had less time to accumulate citations. The regression analysis, when we include year fixed-effects, will remove this bias.

Table 2 also reveals other trends. As expected, the two America-based journals - JEH and Explorations - tend to publish most papers that deal with the Americas. The EHR has a large bias towards Europe 
Table 1: Descriptive statistics of Journals-dataset, 1998-2018

\begin{tabular}{|c|c|c|c|c|c|c|c|c|c|}
\hline Region & Journal & Obs & Order & Issue & Ave-pages & Tot-pages & Ave-aut & Ave-cite & M-cite \\
\hline Africa & EHR & 31 & 5.710 & 3.032 & 24.645 & 764 & 1.581 & 29.871 & 184 \\
\hline Africa & EREH & 7 & 3.143 & 2.143 & 21.857 & 153 & 1.286 & 28.714 & 116 \\
\hline Africa & Explorations & 8 & 4.375 & 2.375 & 23.250 & 186 & 1.750 & 24.375 & 99 \\
\hline Africa & $\mathrm{JEH}$ & 14 & 4.214 & 2.286 & 32.643 & 457 & 1.500 & 32.000 & 126 \\
\hline Americas & EHR & 40 & 5.200 & 2.625 & 24.625 & 985 & 1.775 & 35.975 & 224 \\
\hline Americas & EREH & 17 & 3.412 & 2.235 & 26.647 & 453 & 1.647 & 14.059 & 57 \\
\hline Americas & Explorations & 221 & 3.891 & 2.240 & 19.656 & 4,344 & 1.643 & 27.833 & 228 \\
\hline Americas & JEH & 346 & 4.711 & 2.529 & 26.841 & 9,287 & 1.572 & 41.353 & 427 \\
\hline Asia & EHR & 50 & 4.820 & 2.560 & 24.740 & 1,237 & 1.440 & 16.900 & 102 \\
\hline Asia & EREH & 9 & 3.222 & 2.778 & 23.889 & 215 & 1.778 & 25.444 & 148 \\
\hline Asia & Explorations & 60 & 3.833 & 2.150 & 17.883 & 1,073 & 1.900 & 24.833 & 97 \\
\hline Asia & JEH & 58 & 5.069 & 2.586 & 27.810 & 1,613 & 1.638 & 41.000 & 265 \\
\hline Europe & EHR & 565 & 5.004 & 2.460 & 24.120 & 13,628 & 1.497 & 31.273 & 406 \\
\hline Europe & EREH & 282 & 3.060 & 2.270 & 25.745 & 7,260 & 1.596 & 32.798 & 424 \\
\hline Europe & Explorations & 223 & 3.964 & 2.099 & 18.735 & 4,178 & 1.749 & 39.475 & 1,031 \\
\hline Europe & JEH & 247 & 4.814 & 2.547 & 28.919 & 7,143 & 1.692 & 53.174 & 556 \\
\hline Global & EHR & 24 & 6.500 & 2.250 & 23.542 & 565 & 1.458 & 51.750 & 488 \\
\hline Global & EREH & 26 & 2.769 & 1.731 & 22.192 & 577 & 1.654 & 86.462 & 662 \\
\hline Global & Explorations & 20 & 3.400 & 1.750 & 20.250 & 405 & 1.700 & 66.650 & 272 \\
\hline Global & JEH & 26 & 3.769 & 2.192 & 32.538 & 846 & 1.615 & 78.923 & 356 \\
\hline None & EHR & 3 & 3.667 & 3.333 & 21.000 & 63 & 1.667 & 12.333 & 30 \\
\hline None & EREH & 3 & 5.333 & 2.667 & 10.667 & 32 & 1.000 & 8.667 & 14 \\
\hline None & Explorations & 6 & 4.167 & 1.667 & 11.167 & 67 & 2.000 & 93.167 & 391 \\
\hline None & JEH & 7 & 4.429 & 2.000 & 14.714 & 103 & 1.143 & 50.429 & 199 \\
\hline
\end{tabular}

[Notes] 'Asia' includes Oceania. 'None' refers to papers with no geographic specification. Number is the order number of each paper. Issue is the issue number. A-pages is the average number of pages. T-pages is the sum of pages. A-aut is the average number of authors per paper. A-cite is the average number of Google citations in March 2019. SD-cite is the standard deviation of citations. M-cite is the paper with the most citations. 'EHR' is The Economic History Review. 'Explorations' is Explorations in Economic History. 'JEH' is Journal of Economic History. 'EREH' is the European Review of Economic History. 'America' refers to a paper on any aspect of the economic histories of North or South America. 'Asia' includes the Middle East and Oceania. 


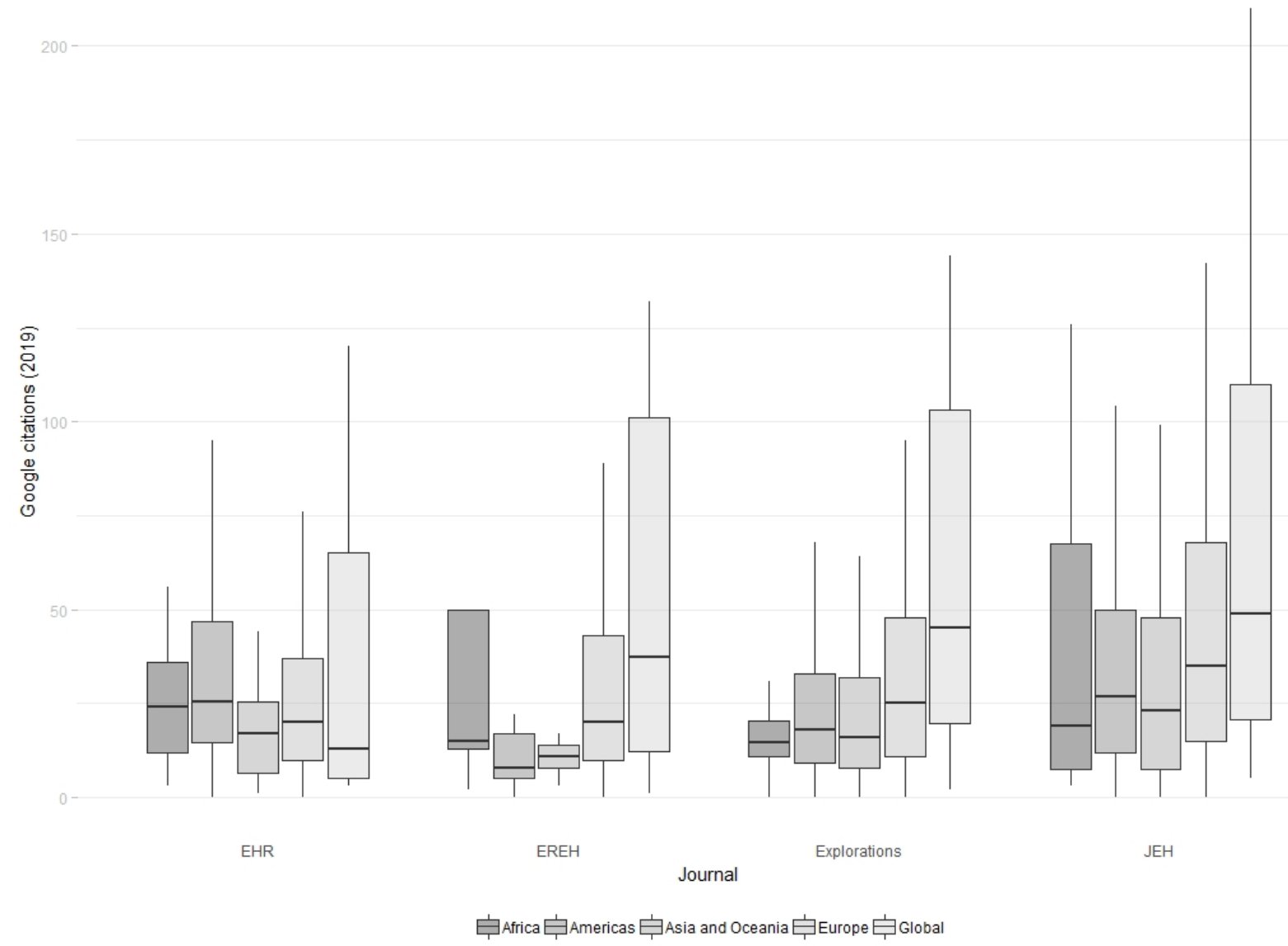

Figure 3: The number of Google citations in March 2019, by journal and region

(which includes the UK, its primary market). The EREH, as its name suggests, publishes papers almost exclusively on European topics (more than 82\%). Explorations seems to be the journal with the most diverse geographical selection of papers, with an equal share between America and Europe and the largest share of Asia and Oceania papers. Yet it is also the journal with the lowest percentage of papers on Africa.

Table 2: Regional share by journal

\begin{tabular}{lrrrrrr}
\hline \hline Journal & Obs & America & Europe & Asia & Africa & Global \\
\hline EHR & 713 & $5.6 \%$ & $79.6 \%$ & $7.0 \%$ & $4.4 \%$ & $3.4 \%$ \\
Explorations & 538 & $41.5 \%$ & $41.9 \%$ & $11.3 \%$ & $1.5 \%$ & $3.8 \%$ \\
JEH & 698 & $50.1 \%$ & $35.7 \%$ & $8.4 \%$ & $2.0 \%$ & $3.8 \%$ \\
EREH & 344 & $5.0 \%$ & $82.7 \%$ & $2.6 \%$ & $2.1 \%$ & $7.6 \%$ \\
\hline
\end{tabular}

[Notes] 'EHR' is The Economic History Review. 'Explorations' is Explorations in Economic History. 'JEH' is Journal of Economic History. 'EREH' is the European Review of Economic History. 'America' refers to a paper on any aspect of the economic histories of North or South America. 'Asia' includes the Middle East and Oceania.

The first result, then, is that while the number of Africa papers has certainly increased significantly over the last decade, Africa still remains on the periphery of economic history research. It is true that a similar case could be made for other world regions; Indian, Indonesian or Chinese economic historians may argue that, given the size of these countries' populations, their economic histories deserve far more attention. That 
Table 3: Author region by region

\begin{tabular}{lrrrrr}
\hline \hline Region & Obs & Americans & Europeans & Asians & Africans \\
\hline Africa & 93 & $19.6 \%$ & $60.8 \%$ & $6.1 \%$ & $13.5 \%$ \\
Americas & 1,003 & $85.6 \%$ & $10.8 \%$ & $3.6 \%$ & $0 \%$ \\
Asia and Oceania & 297 & $28.5 \%$ & $31.4 \%$ & $40.2 \%$ & $0 \%$ \\
Europe & 2,094 & $20.3 \%$ & $76.1 \%$ & $3.6 \%$ & $0 \%$ \\
Global & 154 & $42.5 \%$ & $55.4 \%$ & $2.2 \%$ & $0 \%$ \\
Other & 28 & $64.1 \%$ & $35.9 \%$ & $0 \%$ & $0 \%$ \\
\hline
\end{tabular}

[Notes] 'Americans' refers to authors based in North or South America. 'Asians' include authors in the Middle East and Oceania.

would indeed be a valid argument. But the two points are not mutually exclusive. More should be done to increase the geographical scope of economic history papers in the top journals.

There is one major difference, though, between the Asian and African papers in these journals. This difference can be seen in Table 3. It reports the share of papers by region (these include fractions of papers split by author number), with the regional affiliation of the author. The latter is determined by the university affiliation of the author at the time of publication. ${ }^{3}$ Only $13.5 \%$ of papers about Africa are written by authors based in Africa. These results are significantly different for other regions: $85.6 \%$ of papers about American economic history are written by scholars based in the Americas and $76.1 \%$ of papers on Europe are written by authors based in Europe. Even a region that might also be largely considered a developing region Asia and Oceania - has a high number (40\%) of Asia and Oceania-based authors. It is also telling that no Africa-based author has published on a topic outside of Africa. ${ }^{4}$

In fact, over the last two decades a total of only eight authors based in Africa have published papers in the top four economic history journals. Their affiliations are provided in Table 4. Only one of these authors was based at a research institution outside South Africa. Table 5 reports the nationality of the authors who were based in Africa at the time of publication.

These numbers are not unique to the field of economic history. A recent study of development studies journals finds largely similar patterns; Cummings and Hoebink (2017) report that $43 \%$ of the authors of the 2112 articles in their sample are located in the USA and UK and $43 \%$ are from other developed countries, while only $14 \%$ are from authors in developing countries. Similarly, Chelwa (2017) analyses 10 development economics journals between 2005 and 2015, finding that 75\% of papers on Africa did not have an Africa-based author.

Table 4: Affiliation and publication units

\begin{tabular}{lr}
\hline \hline Affiliation & Publication units \\
\hline Economic Research Southern Africa & 1 \\
Nelson Mandela Metropolitan University & 1 \\
Stellenbosch University & 4 \\
University of Johannesburg & 0.7 \\
University of Nigeria & 1 \\
\hline
\end{tabular}

\footnotetext{
${ }^{3}$ Although nationality would have been the preferred measure, the nationality of authors is not readily available. The results, though, are unlikely to change substantially for Africa.

${ }^{4}$ Again, this may specific to the top four economic history journals. Nigerian scholar Joseph Inikori (2002), although now based in the US, has made a major contribution to the economic historiography of the British Industrial Revolution.
} 
Table 5: Nationality and publication units

\begin{tabular}{lr}
\hline \hline Nationality & Publication units \\
\hline Nigerian & 2 \\
South African & 5.7 \\
\hline
\end{tabular}

One concern may be that these results apply only to the top four journals. This seems to not be the case. In a recent survey of the latest research on sub-Saharan African economic history published in $A n$ Economist's Guide to Economic History, Moradi (2018) cites 34 papers. Only one of them is written by an author based in Africa. A second source of corroborating evidence comes from Fourie and Obikili (2019). They apply an algorithm to 49,444 papers in a database of articles published in 17 economic history journals and the top 25 economics journals published from 1992 to 2016. They then classify them as either economic history or economics. From this list, all papers that include 'Africa' in the title, abstract or keyword section or any of the current or historical names of African countries are chosen. Only 238 papers remain, from which they compile a Euclidean index of the top economic historians working on Africa. Table 6 ranks the top 20 authors.

Table 6: Euclidean index ranking for economic history scholars on 'Africa', 1992-2016

\begin{tabular}{llccccll}
\hline & Author & H-index & E-index & G-index & Cit. & Pub. & Country \\
\hline 1 & Nunn, N. & 5 & 167.2 & 7 & 337 & 7 & USA \\
2 & Austin, G. & 5 & 94.7 & 7 & 171 & 7 & UK \\
3 & Williamson, J. & 4 & 88.7 & 6 & 133 & 6 & USA \\
4 & Huillery, E. & 3 & 68.3 & 3 & 102 & 3 & France \\
5 & Frankema, E. & 7 & 60.9 & 9 & 156 & 9 & Netherlands \\
6 & Richardson, D. & 3 & 41.3 & 3 & 71 & 3 & USA \\
7 & Eltis, D. & 3 & 37.2 & 3 & 60 & 3 & USA \\
8 & Baten, J. & 4 & 35.5 & 4 & 58 & 4 & Germany \\
9 & Robinson, J. & 2 & 32.1 & 3 & 34 & 3 & USA \\
10 & Bates, R. & 2 & 30.1 & 4 & 32 & 4 & USA \\
11 & Shatzmiller, M. & 3 & 28.3 & 3 & 417 & 3 & Canada \\
12 & Allen, R. & 2 & 27.5 & 2 & 32 & 2 & UAE \\
13 & Lewis, F. & 2 & 25.6 & 2 & 33 & 2 & USA \\
14 & Fourie, J. & 3 & 24.8 & 4 & 43 & 4 & South Africa \\
15 & Von Fintel, D. & 3 & 22.8 & 4 & 36 & 4 & South Africa \\
16 & Moradi, A. & 2 & 22.8 & 2 & 30 & 2 & United Kingdom \\
17 & Pamuk, S. & 2 & 18.0 & 2 & 25 & 2 & Turkey \\
18 & Fenske, J. & 4 & 14.9 & 5 & 35 & 10 & UK \\
19 & Jerven, M. & 3 & 13.7 & 3 & 19 & 3 & Norway \\
20 & Van Leeuwen, B. & 2 & 10.6 & 2 & 15 & 2 & Netherlands \\
\hline
\end{tabular}

Despite some shortcomings ${ }^{5}$, the method confirms our results above. Only $10 \%$ of authors on the list are from Africa or based on the African continent, a share not far from the $13 \%$ I find above for African representation in EH journals. Fourie and Obikili conclude: 'African cliometrics is mostly a non-African field'.

\footnotetext{
${ }^{5}$ The authors document, for example, how Nathan Nunn's seminal contribution on slavery is excluded from the list of papers because 'Africa' is neither mentioned in the title, abstract nor keywords of the paper.
} 


\section{Motivations}

Why does it matter that African scholars are not participating in writing the economic histories of Africa? Although there are many reasons, I will mention only two, both of which are especially relevant to African economic history.

The first is that African scholars promote methodological diversity. Africa is relatively poorly endowed with written records of the past. Although this is particularly true of the precolonial period, colonial archives introduce their own biases that require the creative use of tools and methods to tell the histories of those excluded (Fourie 2016). One such alternative source, for example, is oral history. Such methods bring their own challenges, but they do require knowledge of local languages and cultural metaphors that Africa-based scholars are more likely to be familiar with. Even sources produced during the colonial era often require a familiarity with local beliefs and customs and how these may bias colonial records ${ }^{6}$, as anyone who has tried to match family names to ethnic groups can attest to. Indeed, as Mlambo (2018) notes, "[w]hile northernbased scholars are increasingly using cliometrics to analyze statistical databases in studying African economic history, Africa-based scholars continue to use archival materials, oral sources, and ethnographic techniques and depend on a wide variety of disciplines such as economics, anthropology, archaeology, and linguistics in their research.' Local knowledge and diverse methods produce better, more innovative research.

At a more general level, African scholars can also promote epistemological diversity. It is conceivable that the experiences of subjugation and marginalisation of slavery, colonialism and apartheid inevitably lead African scholars to ask critical questions of past power structures and how these have shaped the knowledge produced today. This is best exemplified by the concept of decoloniality. 'At the core of decoloniality', says Ndlovu-Gatsheni (2015, p. 492), 'is the agenda of shifting the geography and biography of knowledge, bringing identity into epistemology - who generates knowledge and from where?'. Using the concept of the coloniality of knowledge, Ndlovu-Gatsheni questions the validity and relevance of knowledge on Africa produced outside Africa. Austin (2015, p. 90) made a similar point: "the fact that the tools we think with (from simple definitions to grand theory) when we analyse African economic history were mostly devised with European, North American or sometimes Indian or Caribbean experience in mind. This does not mean they are necessarily inapplicable to Africa. But the overwhelmingly one-way character of the flow of concepts is probably to the detriment of both importers and exporters'. One way to rephrase the question: Are the research questions currently asked the ones that we should be asking? African scholars may know better.

A second reason to push for greater African participation is to share the spoils of economic history research beyond the narrow disciplinary confines. There are two parts to this. First, African economic history has much to teach other social science fields, including economics, history, political science, development studies and even more distant fields like management, linguistics and geography. Austin (2007, p. 18) also recognised this opportunity: 'If Africa's history is to become fully recognized as a source of illumination into the human condition, or more precisely into human experience, we who study it (in our various disciplines) need to raise our sights. Alongside the task of recognizing the specificity of much of our material is the need to explore the ways in which African histories provide parallels, models, or illuminating contrasts with other histories. We should not be shy about sharing the results of this exploration - both findings and suggestions - with specialists on other continents, and with comparativists and theoreticians. We have long accepted the duty to disseminate the results of Africanist scholarship to students and the public. But, some pioneers excepted, we could try harder to communicate our conclusions to fellow academics: to insist on the principle that comparison be reciprocal, and to provide our share of the tools required to implement it.'

I would argue that African economic historians should not only try to engage fellow academics. The Great Recession of 2007 or the success of Thomas Piketty's work on inequality suggests that economic historians can also contribute to policy debates (Eichengreen 2012; Piketty 2015). This is particularly true in Africa, where economic policies are conditional on the past. Take the case of Rwanda. Heldring (forthcoming) shows, for example, that the violence in Rwanda's recent past can be traced back to the initial establishment of its precolonial state. In those areas with historical exposure to the state, a higher propensity of obedience to the state resulted in lower violence before and after the genocide, but more violence during the genocide. This is because, as Biko (2019, p. 10) writes, 'interpretations of history shape relationships with present-day

\footnotetext{
${ }^{6}$ Doyle et al. (Doyle et al. 2019) reveal, for example, how African patients were over-diagnosed with sexuallytransmitted diseases.
} 
cultural norms and attitudes towards modern institutions'. These norms 'impact on people's freedom of thought, their attitude to rules, their approach to leadership and their economic behaviour'. The lesson is that policy success may rest on the norms, values and behaviours that have been forged by history. African economic historians uncover how these historical forces still shape present realities. And because African scholars are more likely to influence domestic policies, it follows that improving the quantity and quality of African economic history on the continent is also likely to yield better-informed economic policies.

\section{Causes}

Having established that few African scholars publish in economic history journals and motivated why this deserves our attention, the obvious question beckons: why are there so few Africans who publish in economic history journals? One way to examine whether this is simply because no market exists for papers on Africa in economic history is to check whether Africa papers receive fewer citations than papers that cover other geographic areas. We do this in a simple poisson and negative binomial regression framework, where the number of Google citations is the dependent variable and a host of paper characteristics, including the geographical scope of the topic and the author's regional affiliation are included as independent variables. These results are reported in Table 7 .

The final two specifications, when we include year fixed-effects, are of most interest. Dummies for each of the journals are also included. The EHR, EREH and Explorations receive, ceteris paribus, fewer citations than the reference journal, the $J E H$. The four variables at the bottom of the table - the order number, the issue number, the length of the paper and the length of the title - all matter in explaining the number of citations a paper attracts. Shorter titles of longer papers that are published in earlier issues and higher up on the list in a particular issue are more likely to be cited. While interesting, that is not of much importance here. ${ }^{7}$

More importantly, the coefficients of interest here are the region-dummies and the author-dummies. Papers with 'Africa', 'Europe' and 'Global' topics are more likely to attract citations than papers on 'America', the reference category. Papers on 'Asia and Oceania' are not much different from 'America'. The results for the author affiliations differ somewhat depending on the estimation technique. The negative binomial suggests that author affiliation matters little in explaining citations; the poisson suggests there are large differences between 'European' and 'American' authors, on the one hand, and 'Asian' and 'African' authors on the other. Given the low number of papers published by African scholars, though, it is best to be cautious about these interpretations.

The obvious interpretation is that the low numbers of papers on Africa in the top four journals is not because of demand-side reasons. But a cynic may interpret the positive, large and statistically significant coefficient on the 'Africa'-dummy as a sign that editors are too cautious in their acceptance of Africa papers, that they only allow the best papers to be published. One way to test this is to look at rejection rates; if the cynical hypothesis is true, rejection rates for Africa papers should be larger. Although journals do not publish these by region, some do publish submission rates by region. Comparing the submission rate for papers on Africa to the Journal of Economic History for the period 2012-2018 (4.4\%) to publication rates of Africa papers in the same journal for 2014-2018 (7\%) suggests that Africa papers are not more likely to be rejected than papers from other regions. Solutions for the low level of African participation must, ultimately, be found on the supply side.

This is not a new concern. In 2014, Fourie and Gardner (2014) showed that authors from developing countries are not less cited in economic history journals. Instead, they are more likely to submit to and publish in local journals. In response, Green and Nyambara (2015) argue that the relative silence from African scholars is due to methodological differences. 'The roots of these differences are found in the developments of economic history in the Western world and not vice versa, i.e., in the cliometric revolution in the 1960s. Together with the cultural turn in history, the cliometric revolution was partly responsible for the dramatic decline in the interest in Africa's past among economic historians and historians at universities in the Western world in the 1990s. Fortunately, interest in African economic history reappeared in the early twenty-first

\footnotetext{
${ }^{7}$ The controls do matter, though, if Africa papers are systematically more likely to be published in later issues or lower down the list (or, for some odd reason, with longer titles or fewer pages).
} 
century, now clearly influenced by cliometrics. Economic history at African universities has followed a different path. It was less affected by the cliometric revolution and, more importantly, it has managed to survive as a vibrant field of research since the 1990s' (Green and Nyambara 2015, p. 69). Austin (2015) is more pessimistic. He notes that although economic history has seen a renaissance in recent years, 'few of the publications have come from authors based at universities between the Zambezi and the Sahara'. He continues: 'This discrepancy is not new, except in degree. It is partly attributable to resource constraints. But it also reflects both intellectual priorities and the way disciplines are organized. Economics departments in the sub-region have shown little interest in history, especially recently; while history departments are often wary of both quantitative methods and economic theory, reflecting a frequently strong institutional divide between humanities and social sciences. Further, while it is true that economic historians in tropical Africa have been less enamoured with mainstream theory and cliometrics than many of their colleagues elsewhere, on both sides this partly reflects insufficient awareness of others' publications' (Austin 2015, p. 79).

I am more optimistic. A new generation of African economists is already publishing economic history papers, although one would have to look beyond the standard economic history journals. African historians are beginning to recognise the need to equip themselves with new skills and contribute to international debates. In the next section, I discuss ways to draw these African scholars into the field.

\section{$5 \quad$ Recommendations}

I argue that at least three things can be done to encourage more African participation. First, African scholars should be made aware of, and encouraged to, take up the study of African economic history. Only a few economic history departments remain on the continent, and they are struggling for survival. The initial reasons for their existence outside economics departments has also withered with time. It is unlikely that the revival of economic history in Africa will come from stand-alone economic history departments.

The focus should, instead, turn to marketing African economic history to economists. This is not as difficult as it may seem. African economists are aware of the need for context when using economic theories developed elsewhere. They are also cognizant of the poor data often available for African economies and the biases that these might introduce in empirical analyses. Most importantly, African students are ultimately interested in understanding the roots of Africa's (under)development. This is what African economic history is all about. As Diebolt and Haupert (2019) argue in a new paper, cliometrics 'has contributed greatly to our understanding of economic growth and development. The use of history as a crucible to examine economic theory has deepened our knowledge of how, why, and when economic change occurs'. If packaged well, cliometrics, the combination of context (clio) and measurement (metrics), could therefore be an attractive field to African students.

In fact, a search beyond the top economic history journals reveals several young African economists that are already writing economic history papers (Asongu and Kodila-Tedika 2017; Asongu and Nwachukwu 2017). They tend to publish in development or local journals which are unlikely to be read and cited by economic historians. The first obvious thing to do is to draw these scholars into the field. Societies like the Economic History Society of Southern Africa (EHSSA), the only fee-paying African member of the International Economic History Association, or the African Economic History Network should play a pivotal role here. The aim should be to establish more regional societies like the EHSSA, focusing on West Africa or Central and East Africa.

The suggestion that we attract more economists to economic history is not to dismiss the role of historians, or indeed those working in the fields of development studies or African studies. Economic history is a broad church, and the skills of these scholars, notably their knowledge of the content and biases of source materials, interdisciplinary approaches, and the deep historiography of the continent, is vital to a thriving discipline. But historians, if they want to participate in economic history debates, need also to equip themselves with the tools of the data revolution. A good example of this is a project I coordinate at Stellenbosch University - the Biography of an Uncharted People ${ }^{8}$ - that aims to use microdata in creative ways to tell histories of those South Africans that have often been excluded from the standard archival sources used by historians.

Let me turn to the second approach to encourage African participation. Although the top four journals

\footnotetext{
${ }^{8}$ For more information, visit www.unchartedpeople.org.
} 
Table 7: Explaining Google Citations of Economic History publications

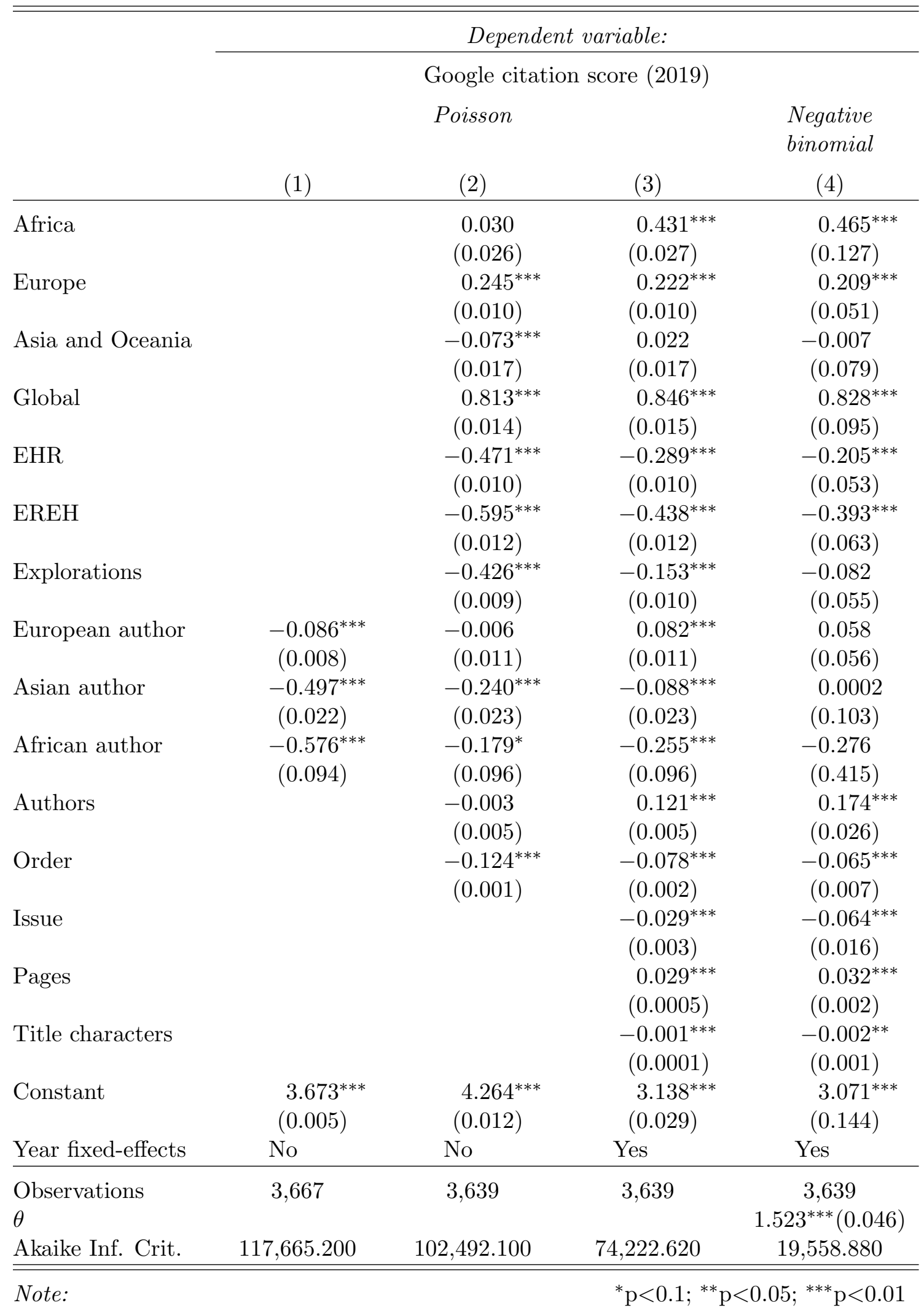

[Notes] ${ }^{*} \mathrm{p}<0.1 ;{ }^{* *} \mathrm{p}<0.05 ;{ }^{* * *} \mathrm{p}<0.01$. 'America' is the reference region, the Journal of Economic History ('JEH') is the reference journal and 'Americans' is the reference author region. 
in economic history, as recent trends suggest, are keen to publish more papers on African economic history, African scholars are often isolated from the networks that are key to publish in these journals. One example of this is that few of the top journals have African economic historians on their editorial board. Table 8 provides the share of Africa specialists and the share of board members based in Africa, by journal. It also includes both shares for Economic History of Developing Regions, a journal aimed at publishing content on developing countries.

Only one scholar based in Africa sits on any of the five editorial boards. That has at least two consequences. First, given that African scholars often use a variety of methods and approaches (Mlambo 2018), a lack of editorial diversity may exclude the contributions of scholars who use these methods or approaches. Second, to the extent that networks of information, influence and collaboration contributes to publication success, this lack of representation is unlikely to contribute to African participation. This is not to suggest that simply adding more African editorial board members will make a meaningful difference, but it reflects the often invisible hurdles African scholars need to clear to be competitive.

There are other ways to remove these hurdles too. One of them is for scholars based at universities outside Africa to visit African universities. This has the advantage of providing larger numbers of students access to insights into methods and skills that would not be affordable if the students were to travel in the opposite direction. A model like this is being followed by the African School of Economics in Benin, a university founded by political scientist (but also well-published economic historian) Leonard Wantchekon. Since 2016, a couple of economic historians travel to Benin to teach African economic history to graduate students in Economics. Several of these students ultimately make their way to the US to enroll in economics degrees. It is not beyond the realms of possibility that one of these students follow their founder into the field of economic history.

Table 8: Share of African specialists (Africanists) and African-based scholars on editorial boards, by journal

\begin{tabular}{lrr}
\hline \hline Journal & Africanist share & Africa-based share \\
\hline EHR & $5.0 \%$ & $0.0 \%$ \\
Explorations & $0.0 \%$ & $0.0 \%$ \\
JEH & $12.5 \%$ & $4.2 \%$ \\
EREH & $0.0 \%$ & $0.0 \%$ \\
\hline EHDR & $30.0 \%$ & $0.0 \%$ \\
\hline
\end{tabular}

Third, a more ambitious (but ultimately more sustainable) way to increase African participation is to support the best African students financially, both in Africa and at universities outside the continent. In South Africa, where almost all the continent's leading research universities are to be found, bursaries are often limited to undergraduate students. At the graduate level, universities have to compete with the high opportunity costs that private sector salaries offer top students. Funding agencies often prioritise STEM research. Joint research projects between African universities and universities in Europe, the US and Asia, as first noted by Austin (2015), with dedicated funding for the most promising African students to either continue their studies in Africa or move abroad, is key if more African scholars are to be drawn into the field. ${ }^{9}$

The good news is that this is beginning to happen. There are several economic history research projects between European universities, like Lund University in Sweden, and my own institution, Stellenbosch University. Lund has not only appointed two former Stellenbosch PhD students, but they have also hired a

\footnotetext{
${ }^{9}$ As one commentator note, there are few incentives for scholars outside Africa to engage with African scholars. Many of the colonial archives are in London, Paris or Lisbon, and the rewards on visiting African archives are not always apparent from the outset. This could change if funding agencies require some form of African participation either to include African students or to partner with local research teams - when doing research on Africa.
} 
former Masters-graduate as a PhD student. ${ }^{10}$ There are other examples as well, although most of these relationships are still weak and contingent on a few individuals.

One concern is that job opportunities in academe are limited for these students once they complete their degrees or postdoctoral positions. Institutes like Ian Phimister's International Studies Group at the University of the Free State in Bloemfontein is one example of how donor funding can be used to sustain an impressive (economic) history research group. These examples should be replicated at other universities, but will require the active collaboration of local research leaders and international funding agencies and donors.

\section{Conclusion}

The United Nations predicts that sub-Saharan Africa's population will rival Asia's population in 2100, comprising close to $40 \%$ of the total global population. While the effects of this population boom remain unclear, what is certain is that Africa's youth, with better education and greater access to information, will demand a deeper understanding of Africa's economic history and its effects on contemporary development outcomes and future prospects. As Biko notes: 'There has to be a different way of thinking about Africa. We have to re-imagine our history in all its glory and depression, just as any other continent would do. We have to make African history ours again. History has to become Our Story.'

The responsibility will be on economic historians to interpret the trajectories of Africa's development. This is exciting. But as I have tried to argue here, this should not just be the purview of economic historians based outside Africa. There is a strong case to make that African scholars should also participate in writing the economic history of their own continent. Although this is not as simple as it sounds - if it was, it would have been done by now - it is, as I've tried to argue above, also not impossible. In fact, there are already signs that this is happening. The number of downloads of the AEHN textbook is a positive sign. The growth of the numbers of papers presented at AEHN conferences, including by African scholars, is a positive sign. And the rise in the number of papers published in top economic history journals by authors based in Africa is certainly a positive sign. As the editor of the AEHN textbook and blog, Meier zu Selhausen (2018), writes: 'African Economic History is set to grow in the years to come. Ideally, this growth would include more researchers from Africa...'.

Above I list some things that can be done to turn this ideal into reality. I argued that societies, associations and networks that aims to promote economic history can begin this process by drawing African economists into economic history. Joint collaboration projects between African universities and universities outside Africa could help equip African students with the tools necessary to participate in international debates. Economic historians (and not only African economic historians) should visit the continent, sharing their expertise, strengthening networks and collaborating with local scholars. And, most ambitiously, donor funding can do much to support scholarships and endowed research positions in African universities that struggle to balance the demands of large undergraduate student numbers and research priorities.

And perhaps we also need to accept that the best papers on Africa need not be published in the European Review of Economic History. The purpose of establishing journals like African Economic History and Economic History of Developing Regions was exactly to provide a platform for scholars, within Africa and beyond, to produce quality work for audiences specifically interested in African economic history. The eight papers on African economic history published in the first two issues of Economic History of Developing Regions in 2019 is one attempt at giving African scholars a platform for their work. In contrast to the 13\% of papers with African topics published by Africa-based scholars, this combined special issue of eight papers features three papers, or $38 \%$, by scholars based in Africa.

An inclusive African economic history is ultimately a more innovative, more relevant and more equitable economic history.

\footnotetext{
${ }^{10}$ The exchange is in both directions. In 2019, associate professor Erik Green is spending a year on sabbatical at Stellenbosch University.
} 


\section{References}

Asongu, S. A. and O. Kodila-Tedika (2017). "Is poverty in the African DNA (Gene)?" In: South African Journal of Economics 85.4, pp. 533-552.

Asongu, S. A. and J. C. Nwachukwu (2017). "The comparative inclusive human development of globalisation in Africa". In: Social Indicators Research 134.3, pp. 1027-1050.

Austin, G. (2007). "Reciprocal comparison and African history: tackling conceptual Eurocentrism in the study of Africa's economic past". In: African Studies Review 50.3, pp. 1-28.

- (2015). "African economic history in Africa". In: Economic history of developing regions 30.1, pp. 79-94.

- (2018). "Three Revolutions in Economic History". In: Inaugural lecture: Cambridge University.

Austin, G. and S. Broadberry (2014). "Introduction: The renaissance of African economic history". In: Economic History Review 67.4, pp. 893-906.

Biko, H. (2019). Africa Reimagined: Reclaiming a sense of abundance and prosperity. Jonathan Ball Publishers SA.

Chelwa, G. (2017). "Does Economics Have an 'Africa Problem'? Some Data and Preliminary Thoughts". In: African perspectives on global corruption conference, Johannesburg, February. Vol. 22.

Cummings, S. and P. Hoebink (2017). "Representation of academics from developing countries as authors and editorial board members in scientific journals: does this matter to the field of development studies?" In: The European Journal of Development Research 29.2, pp. 369-383.

Di Vaio, G. and J. L. Weisdorf (2010). "Ranking economic history journals: A citation-based impactadjusted analysis". In: Cliometrica 4.1, pp. 1-17.

Di Vaio, G., D. Waldenström, and J. Weisdorf (2012). "Citation success: Evidence from economic history journal publications". In: Explorations in Economic History 49.1, pp. 92-104.

Diebolt, C. and M. Haupert (2019). How Cliometrics has Infiltrated Economics - and Helped to Improve the Discipline. Tech. rep. Bureau d'Economie Théorique et Appliquée, UDS, Strasbourg.

Doyle, S., F. Meier zu Selhausen, and J. Weisdorf (2019). "The Blessings of Medicine? Patient Characteristics and Health Outcomes in a Ugandan Mission Hospital, 1908-1970". In: Social History of Medicine.

Eichengreen, B. (2012). "Economic history and economic policy". In: The Journal of Economic History 72.2, pp. 289-307.

Fourie, J. (2016). "The data revolution in African economic history". In: Journal of Interdisciplinary History 47.2, pp. 193-212.

Fourie, J. and L. Gardner (2014). "The internationalization of economic history: A puzzle". In: Economic History of Developing Regions 29.1, pp. 1-14.

Fourie, J. and N. Obikili (2019). "Decolonizing with data: The cliometric turn in African economic history". In: Handbook of Cliometrics. Springer, forthcoming.

Frankema, E., E. Hillbom, U. Kufakurinani, and F. Meier zu Selhausen (2018). The History of African Development: An Online Textbook for a New Generation of African Students and Teachers. African Economic History Network.

Green, E. and P. Nyambara (2015). "The internationalization of economic history: perspectives from the African frontier". In: Economic history of developing regions 30.1, pp. 68-78.

Hamermesh, D. S. (2018). "Citations in economics: measurement, uses, and impacts". In: Journal of Economic Literature 56.1, pp. 115-56.

Heldring, L. (forthcoming). "The Origins of Violence in Rwanda". In: Review of Economic Studies.

Inikori, J. E. (2002). Africans and the Industrial Revolution in England: A study in international trade and economic development. Cambridge University Press. 
Meier zu Selhausen, F. (2018). Africa Rising in Economic History. Blog.

Mlambo, A. (2018). "African Economic History and Historiography". In: Oxford Research Encyclopedia of African History. Oxford University Press.

Moradi, A. (2018). "Sub-Saharan Africa". In: An Economist's Guide to Economic History. Springer, pp. 285-292.

Ndlovu-Gatsheni, S. J. (2015). "Decoloniality as the Future of Africa". In: History Compass 13.10, pp. $485-496$.

Piketty, T. (2015). "About capital in the twenty-first century". In: American Economic Review 105.5, pp. 48-53.

Seltzer, A. J. and D. S. Hamermesh (2018). "Co-authorship in economic history and economics: Are we any different?" In: Explorations in Economic History 69, pp. 102-109. 